\title{
SENECA IN TRANSLATION: A STUDY ON THYESTES BY CARYL CHURCHILL
}

\author{
Preethamol M.K
}

\begin{abstract}
Caryl Churchill has always been a playwright whose area of interest has closely been associated with themes that are of contemporary relevance. With each passing phase of her dramatic career, she was keen to establish her mark as a noted dramatist whose concern with the sufferings of humanity around the world were portrayed in her works. Caryl Churchill's Thyestes is a masterpiece in translation. She has the base for the translation from the very original work by Seneca and his Thyestes. When we study the works by the playwrights from the older generation and their translations by the playwrights of the contemporary times, Thyestes by Churchill confirms the argument that there is not much of a difference when it comes to the themes enjoyed by the people no matter the passage of time.
\end{abstract}

Seneca the Younger is perhaps best popular as a Roman statesman, a Stoic philosopher and still more popular as the tutor to Emperor Nero. Viewing him from a literary point of view, he might be perhaps one among the most instrumental in the evolution of Renaissance drama. This in turn led to the development of authentic tragedy during Elizabethan age, especially the tragedies of Shakespeare which had the elements of horror and the supernatural to name a few. Though most of his dramatic works were not original and had traces of the renowned Greek dramas, he made significant changes in the plays he wrote. His craftsman ship in abandoning and rearranging the scenes from 
the original to weave a beautiful design in the works he crafted is always commendable. Contrary to this trend of adaptation from the Greek pioneers and their original texts, Thyestes by Seneca is a clear deviation from its Greek original and is considered to be his masterpiece. It is believed to have been written around $62 \mathrm{CE}$. Thyestes by Seneca has seen numerous translations.

Caryl Churchill is a postmodern playwright of British origin whose place among the writers of the twentieth century is beyond doubt. She is one of the most accomplished of the women theatre practioners who went an extra step in taking the genre of contemporary drama to new heights. She has won several meritorious awards and was even appointed as the first woman writer in residence at the Royal Court Theatre (1974). Her plays are widely published and performed by renowned theatre groups. She stands foremost as the icon of modern feminist theatre. Her works are characterised by a deep sense of class and gender, balance of power between men and women and how it affects relationships, identifying oppression in society, role of race and patriarchy which makes her beyond doubt a self conscious socialist feminist dramatist. As time passed she matured into a writer who wrote about modern day concerns of ecology and globalisation and questions the ethical alertness of the public.

Thyestes was originally written in accordance with the psychology and mental dimensions of the people of the period of Seneca. As per the story line and the allegiance to Greek mythology, the play is about Atreus' vengeance against his brother Thyestes. But metaphorically the play should be read as a product of the social and political conditions that plagued the milieu of the times of Seneca. The scene of activity has not changed an iota when we cross over to the times of Churchill. The themes and the circumstance remain the same, only the people are seemingly different though they display and are controlled by the same emotions and desires as was during the time of Seneca. Thus we can say that Thyestes by Churchill is a 'good' theatre text and is definitely the one that 'works' and thus be easily interpretable 
and identifiable by both actors and audience. If the audience is capable of decoding what is going on stage, then the success of the playwright is beyond doubt.

As it is the case with popular works in literature, translation from original texts are a common phenomenon. Theatre was a long neglected field in the area of translation. Contrary to translations in other literary genres, one of the pre requisites for translating a dramatic text was that it should be 'actable' and 'performable' on stage. Also the translation was expected to be scholarly on one hand and faithful to the original on the other. Another caution that was to be heeded while translating dramatic texts was the aim of the translated works. There was the need to check if it was aimed at being performed on stage or not. If yes, then there was the need to change to suit the performance on stage. According to Susan Bassnett a play is 'much more than a literary text, it is a combination of language and gesture brought together in a harmonious frame of timing' (Bassnett - McGuire, 1978:161).

In Thyestes the translated version by Churchill, it is closely linked up with the socio cultural circumstance of its conception. The play and the playwright was bravely able to take the cultural, social, historical and geographical situation of the audience into account. While translating from the original, the playwright was able to adapt to the changing circumstances of her times. Thus the translator or even the director had the supreme power to exercise and execute their power as creators. This is because of the fact that they had the freedom to make adjustments or interpret the base text according to the need. But of course the texts have to be changed to suit the performances on stage. According to Susan Bassnett a play is 'much more than a literary text, it is a combination of language and gesture brought together in a harmonious frame of timing' (Bassnett - McGuire, 1978:161).

The notes to Churchill's translation are very elaborate in that there is nothing as extensive as that in any of her other plays. The play portrayed a vision which foretold the violence 
encountered by the people around the world. Seneca was thus instrumental in helping Churchill to write about the terrorism in the 1990s. Churchill also was frank enough to admit that it was typical of her and the time in which she lived to portray the translation in the whole sense of the original. According to Elin Diamond, 'Even as Seneca physicalizes craving, the cosmology of tragedy gives Churchill rein to explore the spatial simultaneity of contemporary terrorism, of there to here.' The playwright has taken the vehicle of the drama which is her forte to respond intelligently to human terrorism. She felt deep for the problems faced by the people in different parts of the world. They were part of a larger humanity who had nobody to help them in times of dire need. Revenge, it has always turned out as an obsession with humans. In this play the very element of revenge is treated, but with an alternate angle to it - the revenge of the gods too. Churchill's gratitude to the Greek and Roman playwrights who might have been her role models in the beginning of her career is best displayed in her modern translation of Thyestes.

Thyestes by Churchill is a modern resurrection of the ancient horror story of the same name written by Seneca. The curse on the house of Atreus is enacted with renewed vigour and is ample proof to the fact that the themes of revenge and terror are always fresh and evergreen and it tantalises the minds of the people. The environment dramatised in the play is enthralling, almost to the point of being immersive. The original Greek myth about the curse on the family of Atreus is abundantly revived in Caryl Churchill's Thyestes. Thus it is a play which is unquestionably a very potent rendering of an undying classic.

Caryl Churchill the renowned dramatist of contemporary England is often termed as a dramatist of social commitments. But her area of expertise can never be pinned down to a particular area. The experiences that she enumerates in her works should be considered as part of the contemporary politics that she is involving herself in. Thus the plays that she has penned cannot be discarded as old or new. They have the charm and the magic of 
the contemporary. Depending on the current area of interest that she has, she makes it a vital point to voice out aloud an opinion and thus place an argument which corresponds truly with her personality of proving a stance.

Caryl Churchill's Thyestes is a masterpiece in translation. She has the base from the very traditional work by Seneca and his Thyestes. When we study the works by the playwrights from the older generation and that of some works by the playwrights of the contemporary times, Thyestes by Churchill confirms the argument that there is not much of a difference when it comes to the themes enjoyed by the people no matter what the passage of time. The social content in the translation marks it as a work which analyses one of the contemporary concerns which Churchill had during the time she wrote her play (1994). The brilliant dramatist in Churchill is able to intermingle the myth associated with the house of Atreus with a modern theme concerning terror and terrorism which had always been her area of concern. She herself has pointed out her viewpoint regarding the contemporary relevance of its content in one of her rare interviews. "I don't think it's just because I've been translating Thyestes that the news seems to be full of revenge stories." (Introduction. Thyestes. 301). One thing that is commendable in Caryl Churchill's translation of Thyestes is she has shown complete allegiance to Seneca. Though the play is modern in its outlook, the readers are able to relate to the references in the play.

The translation of Thyestes is done in an expert manner with no deviation from the old classic. The tragedy is about the revenge that the king of Argos, Atreus took on his brother Thyestes. The features of revenge are best elaborated in the way when we find the infamous banquet scene where a father is unknowingly responsible for eating his children. Thyestes and its elementary theme of revenge have grown through the passage of time and have found its way into other brilliant dramas and works in the ensuing years, especially during the Renaissance and Elizabethan times. 
The drama is a spectacle in vision. Thyestes closely follows the style of linguistic exuberance associated with a revenge play. The language of spectacle is rendered in the best and the choicest of words by Churchill with the right due given to the original creator of the work Seneca. Contrary to the common trait of conflicts arising from the characters, the play Thyestes follows another mode of trajectory. The spectacle is already there in the element of the myth treated in the play which is none other than the curse on the house of Atreus. All the events which are elaborated in the play attributes to the single theme of the revenge taken by Atreus on his brother Thyestes. Thus rhetorical over indulgence and making a spectacle of the gory details associated with the genre of revenge play makes the play a true blue revenge play in the true sense of the term.

The play by Churchill was staged in 1994 and Churchill was renewing her collaborations with Orlando Gough and lan Spink. The modern take on Thyestes by Churchill shows how human beings can be steadfast on the vice of obsession. The dark jealousies that exist between brothers in the contemporary age are best portrayed in the play. Sibling rivalry can grow and develop into new, elaborate and fierce dimensions and how that can tragically affect the peace and calmness of an entire generation is best portrayed in the drama. This shows that the theme of revenge and obsession with the age old theme of sibling rivalry will never go out of charm. In short, the play is a take on how the single element of repetition can pave the way for lifelong intricacies in the family and how that can be a curse to the tragedies concerning and thus affecting future generations.

Thyestes by Churchill should be read as a modern play with contemporary connotations. The play can be an understanding of how certain moral issues can serve as a nagging issue into the mind of a person living in current times. A modern viewpoint is the take on the theme of incest and how it can be passed on from generation to generation. The modern day audience is fascinated by the ancient stories which is the landmark of many 
an issue that they are encountering in their daily existence. We are forced to believe in and relate to these gory tales of violence and incest coupled with greed and despair. We are surprised to find ourselves believing in the ultimate truth that emotions portrayed in the plays are to a great extent universal and it has everything to do with the stark reality and the age in which we live in.

It reminds and leads us to another valid argument. It is true that we are living in the direst of circumstances and also in an extremely violent time where value system has been corrupted and whatever is left is definitely thrown to the winds. Even at the grass root levels of human activity and functioning, the parameters of what is right and what is wrong has lost the morally right deciding factor. Thus basically Seneca and Churchill come into lime light because of this. They never lose their relevance and contemporary outreach. For those who love the classics, especially the Romans and the Greeks, the play Thyestes is a gem of a discovery. Analysing the contemporary relevance of the story of revenge, horror and terrorism, the best time to stage the play by Churchill was the year 1994. In 1994 Churchill was personally affected by the slaughter in Rwanda and the ethnic cleansing in Bosnia. She found the best person in James McDonald the British director to direct her play. Then later on after thirteen years, the play found a revival in the Court Theatre in 2007.

Thyestes has more to it than merely being a revenge tragedy with hoards of violence, sensationalism and bleakness which is commonly attached to it. It is a study in evil which portrays the terrible consequences of anger and thus in turn its horrible manifestation in the form of a behavioural pattern characterised by madness. It can also be seen as a study in the sadistic almost to the point of being narcissistic pleasure that certain people derive from inflicting cruelty. Thyestes pictures a world where power is hideously misused and also a place where gods are biased and lopsided when it comes to taking decisions about the mortals. 
Caryl Churchill must definitely have had in mind many despots who trigger on their elements of revenge and retribution on their own family and associates. Also a question which becomes crucial is if revenge and vengeance is the ultimate when it comes to rectifying retaliation. Again man's capability for cruelty and violence should be addressed in a rightful manner. The end of the play does not put an end to all the questions which arises in the mind of the readers. It gives and leaves us with an open statement that the cycle of violence and revenge will continue.

\section{REFERENCES}

- Aston, Elaine, and Elin Diamond. The Cambridge Companion to Caryl Churchill. Cambridge: Cambridge UP, 2009. Print.

- Bassnett, Susan. Translation Studies. London: Methuen, 1980. Print.

- Churchill, Caryl, lan Spink, David Lan, Caryl Churchill, Orlando Gough, and Lucius Annaeus Seneca. Plays: Three. London: Nick Hern, 1998. Print

- Gobert, R. Darren. The Theatre of Caryl Churchill. N.p.: n.p., n.d. Print.

- Riccardi, Alessandra. Translation Studies: Perspectives on an Emerging Discipline. Cambridge: Cambridge UP, 2002. Print. 